\title{
Comparison of the Long-Term Properties in Compression of Different Size Foamed Concrete
}

\author{
Rihards Gailitis \\ Faculty of Civil Engineering \\ Riga Technical University \\ Riga, Latvia \\ rihards.gailitis@edu.rtu.lv \\ Genadijs Shakhmenko \\ Faculty of Civil Engineering \\ Riga Technical University \\ Riga, Latvia \\ genadijs.sahmenko@rtu.lv
}

\author{
Andina Sprince \\ Faculty of Civil Engineering \\ Riga Technical University \\ Riga, Latvia \\ andina.sprince@rtu.lv \\ Tomass Kozlovskis \\ Faculty of Civil Engineering \\ Riga Technical University \\ Riga, Latvia \\ t.kozlovskis@gmail.com
}

\author{
Leonids Pakrastins \\ Faculty of Civil Engineering \\ Riga Technical University \\ Riga, Latvia \\ leonids.pakrastins@rtu.lv
}

\begin{abstract}
Foamed concrete has been used as a building material since the early 1920s. In the beginning, it was used as an insulation material with very low density. Since then there have been attempts to make this material more loadbearing and structural. In the present-day foamed concrete is being used in soil reinforcement, manufacturing of building blocks and other sorts of construction materials. [1]

The aim of this article is to determine long-term properties and strength of foamed concrete specimens as well as compare the results between two differently sized foamed concrete specimens.

The size of creep and shrinkage specimens were $\varnothing 46 \times 190$ $\mathrm{mm}$ and $\varnothing 75 \times 180 \mathrm{~mm}$. The creep properties of the specimens were determined by loading them with $20 \%$ of the ultimate stress value. [2]

The compressive strength, creep and specific creep of specimens were determined as well as specimen size factor to creep deformations.
\end{abstract}

Keywords-Foamed concrete, long-term properties, creep and shrinkage deformations.

\section{INTRODUCTION}

Typically, foamed concrete is considered to be lightweight, low strength concrete with good thermal insulating properties. [7]. Foamed concrete is a cellular cementitious material obtained by introducing foam in the cement matrix. This introduction gains development of air voids within the microstructure of the material, thus contributing to advantages in properties such as low self-weight, low thermal conductivity, good acoustic absorption, increased fire resistance and workability. Due to this, it is widely used as an exterior insulating material, cavity filling, shock absorption barrier, and fire insulation material. On the other hand, structural voids also reduce the strength of material $[3,4,9]$. It has been well recognized that the compressive strength of foamed concrete decreases as the porosity of the material increases. Because the mechanical properties of a material are mainly affected by its pore structure, its void features are considered in many previous studies [6].

Foamed concrete, conventionally described by the density of $280-1800 \mathrm{~kg} / \mathrm{m}^{3}$, thus a lightweight material. The density of the cellular (foamed) concrete can be controlled by adding a specific amount of foam into the slurry of water and cement, with and without the addition of aggregate. Foam stability is a very important factor for foamed concrete. Unstable foam can cause segregation and uneven density through the material. However, it is relatively difficult to control foam stability because it is affected by various parameters such as foam agent, foam achieving technology, water/cement ratio, and others. Usually, surfactant, protein, synthetic, metal powders and hydrogen peroxide are used as a foaming agent $[4,7-9,12]$.

In relevant literature, a common strategy to increase the strength of foamed concrete without worsening the characteristics associated with low densities is to add different kinds of fibers to the cementitious matrix [3].

Creep is an important quality of concrete since it affects the deformation and stress distribution within the concrete structures. Investigations on concrete creep have lasted for over a hundred years and the findings are considerable.

It has been reported that the factors, affecting concrete creep, are mixture proportion, curing age, environmental temperature, and relative humidity, and applied stress level $[5,11]$.

The aim of this article is to determine and compare the strength and long-term properties of foamed concrete, by observing specimens of two different sizes. In addition, possible reasons for differences in strength and long-term properties shall be noted.

\section{Materials AND MEthods}

Two types of cylindrical specimens were prepared:

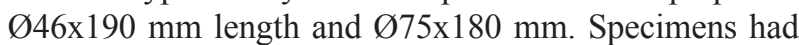
two different foamed concrete mix, that is shown in Table I [10]. 
TABLE I.

TABLE I. FOAMED CONCRETE MIXES

\begin{tabular}{|c|c|c|c|}
\hline \multirow{2}{*}{ Ingredients } & \multirow{2}{*}{ Units } & \multicolumn{2}{|c|}{ Specimen type } \\
\cline { 3 - 4 } Cement CEM I 42.5N & $\mathrm{kg} / \mathrm{m}^{3}$ & 350 & 240 \\
\hline Quartz sand 0/0.5 mm & $\mathrm{kg} / \mathrm{m}^{3}$ & 125 & 300 \\
\hline Quartz sand 0/0.3 mm & $\mathrm{kg} / \mathrm{m}^{3}$ & 75 & - \\
\hline $\begin{array}{c}\text { Foam agent (Tukums) } \\
\text { mixed together with } \\
0.351 \mathrm{H}_{2} \mathrm{O}\end{array}$ & $\mathrm{kg} / \mathrm{m}^{3}$ & 1.8 & 1.05 \\
\hline PP fibers & $\mathrm{kg} / \mathrm{m}^{3}$ & 1.25 & 0.3 \\
\hline $\begin{array}{c}\text { Metakaolin LMK, } \mathrm{kg} \\
\mathrm{kg} / \mathrm{m}^{3}\end{array}$ & 25 & - \\
\hline $\begin{array}{c}\text { Micro silica Elkem } \\
971 \mathrm{U}\end{array}$ & $\mathrm{kg} / \mathrm{m}^{3}$ & 15 & 8 \\
\hline Water & $\mathrm{kg} / \mathrm{m}^{3}$ & 225 & 80 \\
\hline Plastificator Stachema & $\mathrm{kg} / \mathrm{m}^{3}$ & 4 & 3.098 \\
\hline W/C & & 0.643 & 0.333 \\
\hline
\end{tabular}

Compression strength of foamed concrete was determined according to EN 12390-3:2009. The tests were performed 7 and 28 days after specimens were made. A compression machine with the accuracy of $\pm 1 \%$ was used and the rate of loading was $0.7 \mathrm{MPa} / \mathrm{sec}$. (see Fig.1).

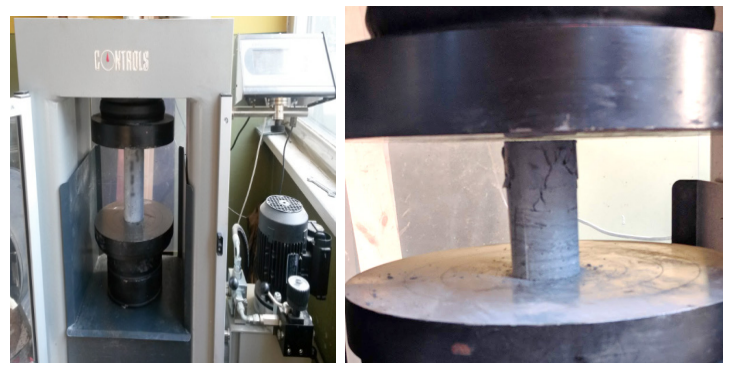

Fig. 1. Specimen compressive strength test.

For creep deformation and shrinkage tests, 6 aluminium plates $(10 \times 15 \mathrm{~mm})$ were glued to each specimen in pairs. Afterward, to those plates deformation indicators were attached (see Fig.2 and Fig.3).
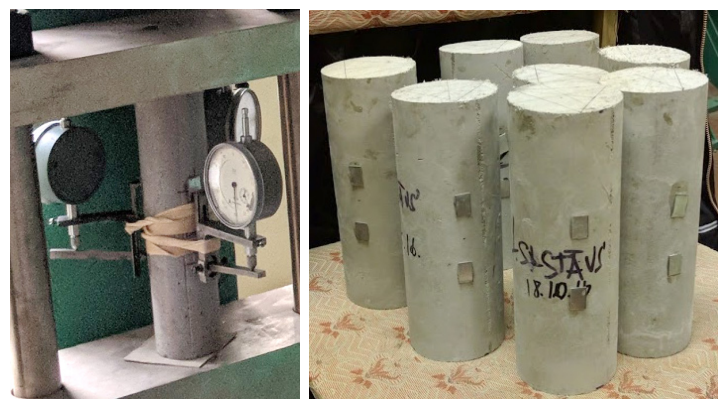

Fig. 2. Specimens prepared for creep testing.

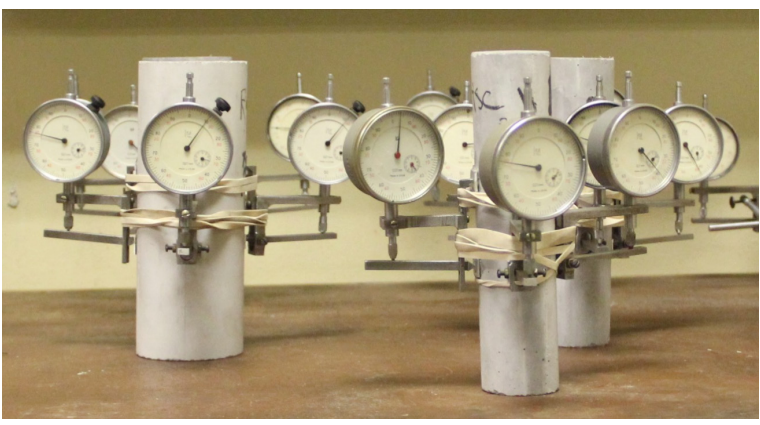

Fig. 3. Specimens prepared for shrinkage testing.

The creep was measured for foamed concrete specimens subjected to a uniform compressive load, which was constant through all the creep test [2]. Meanwhile, the shrinkage test was also performed to register deformations caused by foamed concrete shrinkage. Afterward, shrinkage deformation values were subtracted from creep test results in order to evaluate only the load impact on the specimens.

During creep tests, specimens were loaded with $20 \%$ of the ultimate compressive load, which was determined in compression strength tests. Specimens were loaded gradually by adding $25 \%$ of the determined load value. Specimens were kept in creep lever test stands (see Fig.4 and Fig.5), loaded under constant load for 53 days.

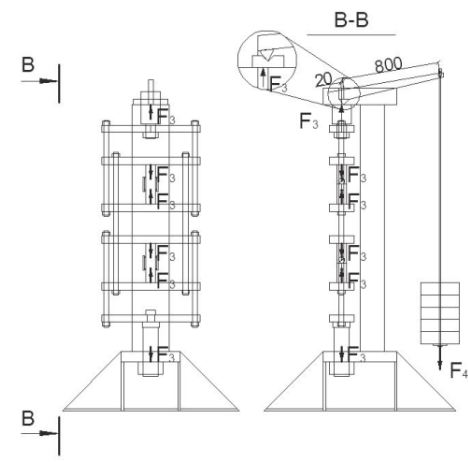

Fig. 4. Creep lever test stand [2].

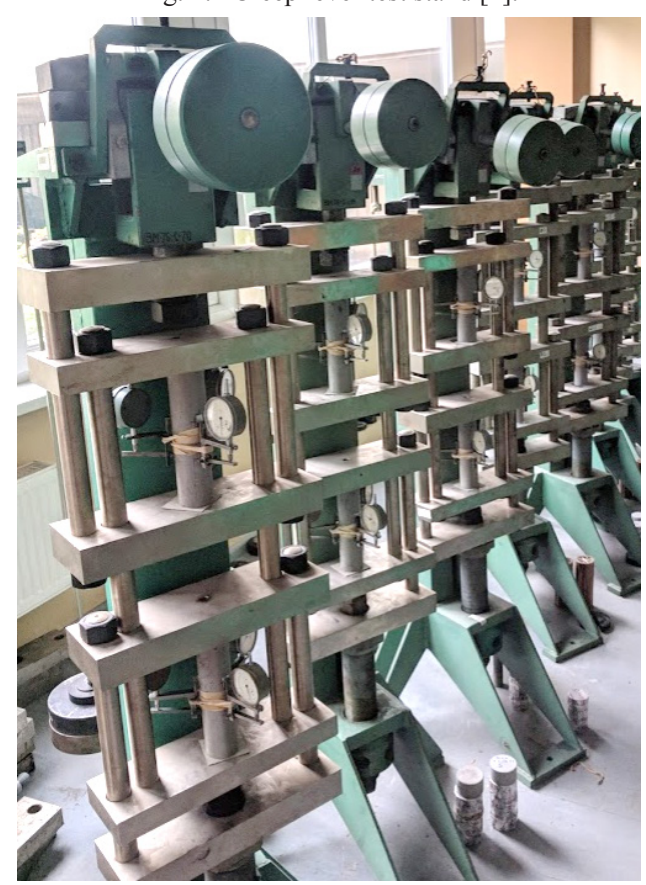

Fig. 5. Creep lever test stands with foamed concrete specimens inserted. 


\section{RESULTS AND DISCUSSION}

The tests to determine compressive strength, creep deformations and specific creep was done.

The density for specimens is shown in Table II.

TABLE II. FOAMED CONCRETE SPECIMEN DENSITIES

\begin{tabular}{|c|c|}
\hline Specimen type & Average density, $\mathbf{~ k g} / \mathbf{m}^{3}$ \\
\hline$\varnothing 46 \times 190 \mathrm{~mm}, 28$ days old & 1276.89 \\
\hline$\varnothing 75 \times 180 \mathrm{~mm}, 7$ days old & 1097.24 \\
\hline$\varnothing 75 \times 180 \mathrm{~mm}, 28$ days old & 1096.23 \\
\hline
\end{tabular}

Compressive strength values of foamed concrete specimens 7 and 28 days after specimens were made are shown in Table III.

TABLE III.

FOAMED CONCRETE COMPRESSIVE STRENGTH

\begin{tabular}{|c|c|c|}
\hline Specimen type & $\begin{array}{c}\text { Average compressive } \\
\text { load, } \mathbf{k N}\end{array}$ & $\begin{array}{c}\text { Average compressive } \\
\text { strength, } \mathbf{M P a}\end{array}$ \\
\hline $\begin{array}{c}28 \text { days old } \\
\varnothing 46 \times 190 \mathrm{~mm}\end{array}$ & 13.80 & 8.32 \\
\hline $\begin{array}{c}7 \text { days old } \\
\varnothing 75 \times 180 \mathrm{~mm}\end{array}$ & 17.54 & 4.56 \\
\hline $\begin{array}{c}28 \text { days old } \\
\varnothing 75 \times 180 \mathrm{~mm}\end{array}$ & 36.20 & 9.41 \\
\hline
\end{tabular}

From Fig.6 it is visible that for both types of cylindrical specimen absolute deformation values show small difference, with a slight increase to $\varnothing 46 \times 190 \mathrm{~mm}$ specimens from 11 th to 33rd day.

Foamed concrete specimens total creep deformations in Fig. 6 are shown with shrinkage values subtracted.

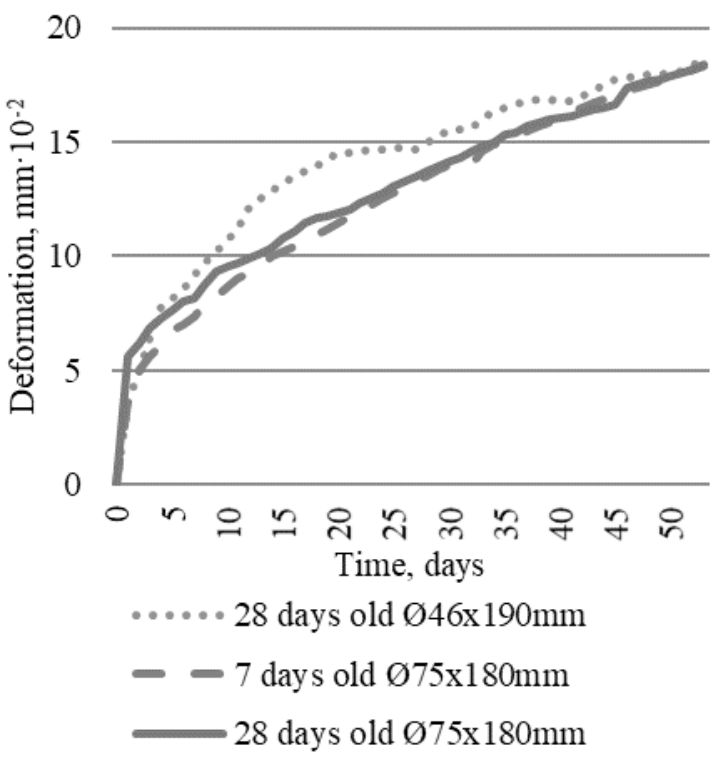

Fig. 6. Foamed concrete specimen total deformations.

Due to different sizes of the test specimens, absolute creep values are not relevant to be taken into account in order to evaluate materials ability to creep. Therefore, specific creep values were calculated to obtain more objective results.

Specific creep value is calculated: relative creep deformation divided by applied stress value. This method excludes circumstances such as the difference in the specimen geometry as well as differences in applied stress levels [2].

Specific creep can be calculated using the following equation:

$$
X_{c r}\left(t, t_{0}\right)=\frac{\varepsilon_{c r}\left(t, t_{0}\right)}{\sigma}=\frac{\varepsilon_{k o p}(t)-\varepsilon_{s h}(t)-\varepsilon_{e l}\left(t, t_{0}\right)}{\sigma}=\frac{1}{E_{c r}\left(t, t_{0}\right)}
$$

$\chi_{\text {cr }}\left(t, t_{0}\right)$ is a specific creep,

$\varepsilon_{\mathrm{cr}}\left(\mathrm{t}, \mathrm{t}_{0}\right)$ is a creep strain,

$\varepsilon_{\text {kop }}(\mathrm{t})$ is a total strain,

$\varepsilon_{\text {sh }}(\mathrm{t})$ is shrinkage strain,

$\varepsilon_{\mathrm{el}}\left(\mathrm{t}, \mathrm{t}_{0}\right)$ is elastic strain,

$\sigma$ is the compressive stress,

$\mathrm{E}_{\mathrm{cr}}\left(\mathrm{t}, \mathrm{t}_{0}\right)$ is the modulus of creep

Specific creep can be measured as micro-strains to megapascal.

From Fig. 7 it is apparent that 7 days old $\varnothing 75 \times 180$ $\mathrm{mm}$ specimens show almost twice as big specific creep as the 28 days old $\varnothing 75 \times 180 \mathrm{~mm}$ specimens. The 28 days old Ø46x190 mm specimens show slightly increased specific creep, compared to the 28 days old $\varnothing 75 \times 180 \mathrm{~mm}$ specimens.

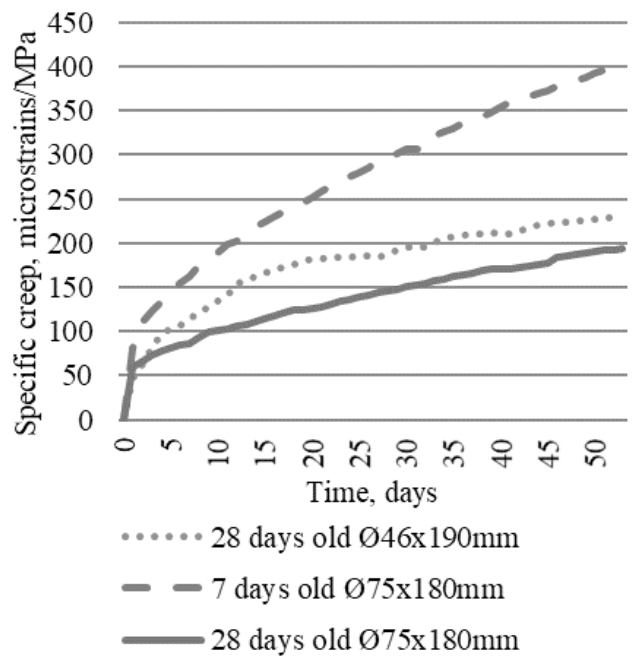

Fig. 7. Foamed concrete specimen specific creep.

\section{Conclusions}

The creep properties of differently sized foamed concrete specimens were determined by performing 53 days long creep test. Also, compressive strength has been determined during this test. According to results that have been obtained, the following conclusions can be drawn:

- From Fig.7 it is determined, the specimens with bigger diameter has relatively lower specific creep. The 7 days old $\varnothing 75 \times 180 \mathrm{~mm}$ specimens show twice as big specific creep as the 28 days old Ø46x190 mm specimens. Comparing 28 days old specimens, more likely to creep (with higher specific creep values) are Ø46x190 mm specimens (difference by 17\%). This increase in specific creep can be related to specimen compressive strength., 28 days old $\varnothing 75 \times 180 \mathrm{~mm}$ specimens have $12 \%$ higher compressive strength than Ø46x190 mm specimens.

- In 28 days after creating the test specimens, larger specimens are $14 \%$ less dense than smaller specimens, whereas the difference in compressive strength is not significant. The compressive strength of $\varnothing 75 \times 180 \mathrm{~mm}$ specimen is only $12 \%$ higher than 
small specimen compressive strength.

- Creep deformations for $\varnothing 75 \times 180 \mathrm{~mm}$ specimens loaded on 7 th or 28th day are almost similar. The only difference in creep deformations is in earlier test stages when there is a small increase in creep deformations for specimens loaded 30 days after they were made.

- Absolute creep deformations for Ø46x190 mm and $\varnothing 75 \times 180 \mathrm{~mm}$ specimens slightly differ. Larger creep deformations have been registered over 11th to 33rd day of testing for $\varnothing 46 \times 190 \mathrm{~mm}$ specimens. From these results, it can be determined that linear relevance between applied stresses and creep deformations, that in stress level of $20 \%$ from the ultimate stress value has to be linear, better appears to be happening for $\varnothing 75 \times 180 \mathrm{~mm}$ specimens. All in all, it has to be mentioned that in linear creep testing RILEM TC 107-CSP recommendation (suggests to use creep specimens with dimensions ratio of $1 / 4$ regarding cylinder diameter and length/ height) is relative and achieved deformations values will be similar to dimension ratio of $1 / 2$ (cylinder diameter to length/ height).

\section{ACKNOWLEDGMents}

This research is funded by the Latvian Council of Science, project 'Long-term properties of innovative cement composites in various stress-strain conditions', project No. lzp-2018/2-0249.

\section{REFERENCES}

[1] Y. H. Mugahed Amran, N. Farzadnia, A.A. Abang Ali. Properties and applications of foamed concrete; a review. Construction and Building Materials 101, 2015. - pp 990-1005.

[2] A. Sprince Methodology For Determination of Long Term Properties and Crack Development Research in Extra Fine Aggregate Cement Composites. PhD Thesis - Rīga: [RTU]. 2015.-70-77. lpp, 172.p.

[3] D. Falliano, D. De Domenico, G. Ricciardi, E. Gugliandolo. Compressive and flexural strength of fiber-reinforced foamed concrete: Effect of fiber content, curing conditions and dry density. Construction and building materials 198, 2019 -pp 479-493.

[4] H.Suleyman Gokce, D. Hatungimana, K. Ramyar. Effect of fly ash and silica fume on hardened properties of foam concrete. Construction and building materials 194, 2019 -pp 1-11.

[5] S. Liang, Y. Wei. Methodology of obtaining intrinsic creep property of concrete by flexural deflection test. Cement and Concrete Composites 97, 2019 -pp 288-299.

[6] T. T. Nguyen, H. H. Bui, T. D. Ngo, G. D. Nguyen. Experimental and numerical investigation of influence of air-voids on the compressive behaviour of foamed concrete. Materials \& Design 130, 2017 -pp 103119.

[7] T. T. Nguyen, H. H. Bui, T. D. Ngo, G. D. Nguyen, M. U. Kreher. A micromechanical investigation for the effects of pore size and its distribution on geopolymer foam concrete under uniaxial compression. Engineering Fracture Mechanics 209, 2019 -pp 228-244.

[8] S.Ghorbani, S. Ghorbani, Z. Tao, J. de Brito, M. Tavakkolizadeh. Effect of magnetized water on foam stability and compressive strength of foam concrete. Construction and Building Materials 197, 2019 -pp 280-290.

[9] T. Li, Z. Wang, T. Zhou, Y. He, F. Huang. Preparation and properties of magnesium phosphate cement foam concrete with $\mathrm{H}_{2} \mathrm{O}_{2}$ as foaming agent. Construction and Building Materials 205, 2019 -pp 566-573.

[10] RILEM TC 107-CSP: Creep and shrinkage prediction models: principles of their formation. Measurement of time-dependent strains of concrete. Materials and structures/Matériaux et Constructions, Vol. 31, October 1998, -pp 507-512. [Online]. Available: https://www. researchgate.net/publication/280141856 RILEM TC 107-CSP CREEP_AND_SHRINKAGE_PREDICTTION_MODELLS_PRINCIPLES OF THEIR FORMATION Recommendation Measurement of time-dependent strains of concrete. [Accessed: March 3, 2019.].

[11] A. M. Neville (2002) Creep of Concrete and Behaviour of Structures. Concrete International No.5., 2002 -pp 52-55

[12] L. F. Kazanskaya, O.M. Smirnova. Supersulphated Cements with Technogenic Raw Materials. International Journal of Civil Engineering and Technology, 9(11), 2018, pp.3006-3012. 